\title{
Knowledges, attitudes and practices in university students about sexual and reproductive health and HIV/AIDS In Bogotá D.C., Colombia
}

Oscar David Diaz-Sotelo ${ }^{1,2}$

From $16^{\text {th }}$ International Symposium on HIV and Emerging Infectious Diseases

Marseille, France. 24-26 March 2010

\section{Background}

To identify protection and risk factors, behavioral and cognitive, in university students about sexual and reproductive health, including STDs and HIV infection.

\section{Methods}

An epidemiological descriptive cross-sectional study was carried out in students selected for multistage cluster method. Participants were surveyed through KAP questionnaire on web-based platform after having received informed consent. The survey was constructed based on similar surveys and was previously validated $(\alpha=0.73)$ and collected data on knowledge and attitudes regarding sexual behaviors. Data analysis was descriptive on SPSS.

\section{Results}

72 students from two universities (mean age 22, 70\% female) were surveyed. $50 \%$ considered knowing enough about sexuality, but 33\% doesn't recognize mechanisms of STDs/HIV transmission rightly and 57\% doesn't associate healthy behaviors with prevention, although $82 \%$ adequately recognize the symptoms of STDs. In addition, 25\% expressed stigma attitudes towards HIVdiagnosed people and 31\% showed low self-efficacy for protection decisions in their sexual practices. Only 13\% reported using condom always and 39\% used it in their last sexual intercourse; $50 \%$ reported sexual intercourse under alcohol effect and 10\% under other psychoactive substances effect. 33\% expressed having been tested for HIV.
Correspondence: oscardaviddiaz@gmail.com

'Universitat Autònoma de Barcelona, Barcelona, Spain

\section{Discussion}

Risky behaviors and attitudes about sex in university students make this study relevant. Prevention programs are not enough for education and awareness focused to young population and this issue contributes to continuing increase in STDs and HIV incidence. These results are an invitation for institutions to develop more appropriate prevention programs and work on psychological and social component of youth sexuality.

\section{Author details}

'Universitat Autònoma de Barcelona, Barcelona, Spain. ${ }^{2}$ RANDOM

Foundation, Bogotá D.C., Colombia.

Published: 11 May 2010

doi:10.1186/1742-4690-7-S1-P115

Cite this article as: Diaz-Sotelo: Knowledges, attitudes and practices in university students about sexual and reproductive health and HIV/AIDS In Bogotá D.C., Colombia. Retrovirology 2010 7(Suppl 1):P115.

Submit your next manuscript to BioMed Central and take full advantage of:

- Convenient online submission

- Thorough peer review

- No space constraints or color figure charges

- Immediate publication on acceptance

- Inclusion in PubMed, CAS, Scopus and Google Scholar

- Research which is freely available for redistribution

Submit your manuscript at www.biomedcentral.com/submit
C Biomed Central 